\title{
Front Matter: Volume 10120
}

, "Front Matter: Volume 10120," Proc. SPIE 10120, Complex Light and Optical Forces XI, 1012001 (6 June 2017); doi: 10.1117/12.2276182

SPIE. Event: SPIE OPTO, 2017, San Francisco, California, United States 


\title{
PROCEEDINGS OF SPIE
}

\section{Complex Light and Optical Forces XI}

\author{
David L. Andrews \\ Enrique J. Galvez \\ Jesper Glückstad \\ Editors
}

31 January-2 February 2017

San Francisco, California, United States

Sponsored and Published by

SPIE 
The papers in this volume were part of the technical conference cited on the cover and title page. Papers were selected and subject to review by the editors and conference program committee. Some conference presentations may not be available for publication. Additional papers and presentation recordings may be available online in the SPIE Digital Library at SPIEDigitallibrary.org.

The papers reflect the work and thoughts of the authors and are published herein as submitted. The publisher is not responsible for the validity of the information or for any outcomes resulting from reliance thereon.

Please use the following format to cite material from these proceedings:

Author(s), "Title of Paper," in Complex Light and Optical Forces XI, edited by David L. Andrews, Enrique J. Galvez, Jesper Glückstad, Proceedings of SPIE Vol. 10120 (SPIE, Bellingham, WA, 2017) Seven-digit Article CID Number.

ISSN: 0277-786X

ISSN: 1996-756X (electronic)

ISBN: 9781510606814

ISBN: 9781510606821 (electronic)

Published by

SPIE

P.O. Box 10, Bellingham, Washington 98227-0010 USA

Telephone +1 3606763290 (Pacific Time) · Fax +1 3606471445

SPIE.org

Copyright @ 2017 , Society of Photo-Optical Instrumentation Engineers.

Copying of material in this book for internal or personal use, or for the internal or personal use of specific clients, beyond the fair use provisions granted by the U.S. Copyright Law is authorized by SPIE subject to payment of copying fees. The Transactional Reporting Service base fee for this volume is $\$ 18.00$ per article (or portion thereof), which should be paid directly to the Copyright Clearance Center (CCC), 222 Rosewood Drive, Danvers, MA 01923. Payment may also be made electronically through CCC Online at copyright.com. Other copying for republication, resale, advertising or promotion, or any form of systematic or multiple reproduction of any material in this book is prohibited except with permission in writing from the publisher. The CCC fee code is 0277-786X/17/\$18.00.

Printed in the United States of America.

Publication of record for individual papers is online in the SPIE Digital Library.

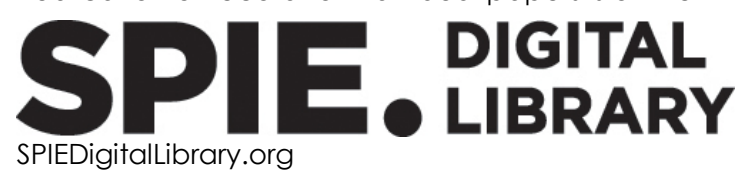

Paper Numbering: Proceedings of SPIE follow an e-First publication model. A unique citation identifier (CID) number is assigned to each article at the time of publication. Utilization of CIDs allows articles to be fully citable as soon as they are published online, and connects the same identifier to all online and print versions of the publication. SPIE uses a seven-digit CID article numbering system structured as follows:

- The five digits correspond to the SPIE volume number.

- The last two digits indicate publication order within the volume using a Base 36 numbering system employing both numerals and letters. These two-number sets start with 00, 01, 02, 03, 04, $05,06,07,08,09,0 A, 0 B \ldots$. OZ, followed by 10-1Z, 20-2Z, etc. The CID Number appears on each page of the manuscript. 


\title{
Contents
}

\author{
vii Authors \\ ix Conference Committee \\ xi Introduction
}

\section{SESSION 1 VECTOR POLARIZATION}

1012003 Characterization of the unfolding process of an optical vortex (Invited Paper) [10120-2]

1012004 Vortex beams and optical activity of sucrose [10120-3]

1012005 Precise transverse alignment of a vectorial optical field generator for complex optical field generation [10120-4]

\section{SESSION 2 OPTICAL VORTEX GENERATION}

1012006 Optical vortex generation by use of vector beam recorded azo-dye-doped liquid-crystal polymer composites [10120-5]

1012008 Optimizing beams with transverse vortices [10120-7]

1012009 Photon sieves for creating and identifying orbital angular momentum of light [10120-8]

SESSION 3 BEAM PROPERTIES

10120 OB Deducing 3-dimensional polarization fields from projective measurements [10120-10]

10120 OD Geometrical interpretation of quantum weak measurement [10120-13]

\section{SESSION 4 OPTICAL ANGULAR MOMENTUM}

10120 OE Pulse, polarization and topology shaping of polariton fluids (Invited Paper) [10120-15]

10120 OF Parallel transport of fiber mode structure: orbit-orbit interaction [10120-16]

$101200 \mathrm{G}$ Vortex-MEMS filters for wavelength-selective orbital-angular-momentum beam generation [10120-17] 


\section{SESSION 5 OPTICAL STRUCTURING AND FABRICATION}

10120 0J Development and characterization of a microsnap-fit for optical assembly [10120-20]

SESSION 6 CHIRAL INTERACTIONS

10120 OM Searching for the helical-gradient force on chiral molecules [10120-23]

10120 ON Orientated molecular information from chiral rotational spectroscopy [10120-24]

SESSION 7 STRUCTURED BEAMS

10120 OP Exploiting the spatial profiles of light (Invited Paper) [10120-26]

$101200 Q$ High-order Poincaré sphere with flower modes possessing orbital angular momentum (Invited Paper) [10120-27]

10120 OS Array-specific propagation of flexibly structured ultrashort pulses [10120-29]

SESSION 8 OPTICAL INFORMATION

$10120 \mathrm{OV}$ Exploring topological phases in quantum walks of twisted light [10120-32]

10120 OW Measuring the non-separability of optical fields [10120-33]

10120 0X Quantum-key distribution with vector modes [10120-34]

SESSION 9 OPTICAL SINGULARITIES

10120 oY Single-beam acoustical tweezers (Invited Paper) [10120-35]

$101200 Z$ A mathematical toolbox for dark ray optics (Invited Paper) [10120-36]

1012010 Light fields behind microstructures: study of the Babinet-principle in the Fresnel regime [10120-37]

\section{SESSION 10 OPTICAL FORCES}

1012014 Topological dynamics near exceptional points in an optomechanical system [10120-41]

iv 
SESSION 11 OPTICAL MANIPULATION

1012017 Confining Brownian motion of single nanoparticles in an ABELtrap (Invited Paper)

[10120-44]

1012018 Optical cell sorting with multiple imaging modalities [10120-45]

$101201 \mathrm{~A} \quad$ Light robotics: an all-optical nano- and micro-toolbox [10120-47]

POSTER SESSION

10120 1B Propagation of Laguerre-Gaussian vortex beams through mouse brain tissue [10120-14]

10120 1C Properties of null knotted solutions to Maxwell's equations [10120-48] 
Proc. of SPIE Vol. $101201012001-6$

Downloaded From: https://www.spiedigitallibrary.org/conference-proceedings-of-spie on 26 Apr 2023 Terms of Use: https://www.spiedigitallibrary.org/terms-of-use 


\section{Authors}

Numbers in the index correspond to the last two digits of the seven-digit citation identifier (CID) article numbering system used in Proceedings of SPIE. The first five digits reflect the volume number. Base 36 numbering is employed for the last two digits and indicates the order of articles within the volume. Numbers start with $00,01,02,03,04,05,06,07,08,09,0 A, 0 B . .0 Z$, followed by 10-1Z, 20-2Z, etc.

Alfano, Robert R., 04, 0Q, 1B

Andersen, G. P., 09

Anderson, M., 09

Ashrafi, Solyman, 04

Asmolova, O., 09

Ballarini, Dario, $\mathrm{OE}$

Bañas, Andrew, 18

Banas, Andrew, $1 \mathrm{~A}$

Baresch, Diego, OY

Barnett, Stephen M., ON

Bendau, Ethan, 04

Bock, M., OS

Börsch, Michael, 17

Cameron, Robert P., ON

Cardano, Filippo, OV

Carrissemoux, Caro, 18

Cesar, Julijan, OG

Chakravarthy, Pradeep T., OF

Chen, Jian, 05

Chipouline, Arkadi, OG

Colas, David, OE

Cumming, M. A., 09

Dagvadorj, Galbadrakh, OE

De Giorgi, Milena, OE

Dienerowitz, Maria, 17

Dominici, Lorenzo, OE

Donati, Stefano, OE

Dudley, A., OP

Dutta, Ishir, OB, OM

Esen, C., OJ

Ferrando, Albert, $\mathrm{OZ}$

Forbes, A., OP, OW, OX

Galvez, Enrique J., OB, OM, 11

García-March, M. A., OZ

Gianfrate, Antonio, OE

Gigli, Giuseppe, OE

Glückstad, Jesper, 18, 1 A

Götte, Jörg B., ON

Gottschall, Thomas, 17

Gozali, Richard, 04

Grunwald, R., OS

Gurbatov, Stanislav O., OG

Haidar, Mohammad T., OG

Harris, J. G. E., 14

Heitkamp, Thomas, 17

Hernandez-Aranda, R. I., OX

Herzig, Hans Peter, 10

Huang, Teng-De, $0 Q$

Jiang, Luyao, 14
Jones, J. A., OM

Kawatsuki, Nobuhiro, 06

Khajavi, Behzad, OM, 11

Kim, Myun-Sik, 10

Köhler, J., OJ

Kong, Lingjiang, 05

Konrad, T., OX

Ksouri, S. I., OJ

Küppers, Franko, OG

Kutlu, Y., OJ

Laussy, Fabrice P., OE

Limpert, Jens, 17

Lindwasser, Lukas, 1B

Lu, Ting-Hua, $0 Q$

Lyubopytov, Vladimir S., OG

Malekizandi, Mohammadreza, OG

Marchiano, Régis, OY

Mason, David, 14

McLaren, M., OW

Mills, J., OM

Miyamoto, Yoko, 03

Naik, Dinesh N., OF

Nape, I., OX

Ndagano, B., OW, OX

Noda, Kohei, 06

Ono, Hiroshi, 06

Ostendorf, A., OJ

Painter, J., OM

Palima, Darwin, 18, 1A

Paul, Sujoy, OG

Perez-Garcia, B., OX

Porfirev, Alexei P., OG

Preece, Daryl, 08

Puthankovilakam, Krishnaparvathy, 10

Regan, B., OM

Rodríguez-Contreras, Adrián, 1B

Rosales-Guzmán, C., OP, OW

Roux, F. S., OX

Rubinsztein-Dunlop, Halina, 08

Sakamoto, Moritsugu, 06

Samlan, C. T., OD

Sánchez Muñoz, Carlos, OE

Sanvitto, Daniele, OE

Sasaki, Tomoyuki, 06

Scharf, Toralf, 10

Scholes, S., OX

Schumann, Martin F., OG

Shi, Lingyan, 1B

Smith, Gregory, 1C 
Sroor, H., OW

Strange, Paul, 1C

Szymańska, Marzena H., OE

Thomas, Jean-Lovis, OY

Tien, Tran Minh, 06

Treffer, A., OS

Trichilli, A., OP

Villangca, Mark, 18, 1A

Viswanathan, Nirmal K., OD, OF

Voelkel, Reinhard, 10

Vyas, Sunil, 03

Wallrabe, U., OS

Wan, Chenhao, 05

Wang, Wubao, 1B

Wegener, Martin, OG

Xu, Haitan, 14

Zhan, Qiwen, 05

Zhang, Lin, 04 


\title{
Conference Committee
}

\author{
Symposium Chairs
}

Jean-Emmanuel Broquin, IMEP-LAHC (France)

Shibin Jiang, AdValue Photonics, Inc. (United States)

Symposium Co-chairs

Connie J. Chang-Hasnain, University of California, Berkeley (United States)

Graham T. Reed, Optoelectronics Research Centre, University of Southampton (United Kingdom)

Program Track Chair

David L. Andrews, University of East Anglia (United Kingdom)

Conference Chairs

David L. Andrews, University of East Anglia (United Kingdom)

Enrique J. Galvez, Colgate University (United States)

Jesper Glückstad, Technical University of Denmark (Denmark)

Conference Program Committee

Robert R. Alfano, The City College of New York (United States)

Cornelia Denz, Westfälische Wilhelms-Universität Münster (Germany)

Kishan Dholakia, University of St. Andrews (United Kingdom)

Wolfgang A. Ertmer, Leibniz Universität Hannover (Germany)

Andrew Forbes, University of the Witwatersrand (South Africa) and

CSIR National Laser Centre (South Africa)

Jörg B. Götte, Max-Planck-Institut für Physik komplexer Systeme (Germany)

David G. Grier, New York University (United States)

Rüdiger Grunwald, Max-Born-Institut für Nichtlineare Optik und Kurzzeitspektroskopie (Germany)

Simon Hanna, University of Bristol (United Kingdom)

Jandir M. Hickmann, Universidade Federal do Rio Grande do Sul (Brazil)

Lorenzo Marrucci, Università degli Studi di Napoli Federico II (Italy)

Giovanni Milione, NEC Laboratories America, Inc. (United States)

Miles J. Padgett, University of Glasgow (United Kingdom)

Darwin Palima, Technical University of Denmark (Denmark)

Daryl Preece, University of California, San Diego (United States) 
Monika Ritsch-Marte, Medizinische Universität Innsbruck (Austria)

Halina H. Rubinsztein-Dunlop, The University of Queensland (Australia)

Marat S. Soskin, Institute of Physics (Ukraine)

Grover A. Swartzlander Jr., Rochester Institute of Technology

(United States)

Nirmal K. Viswanathan, University of Hyderabad (India)

\section{Session Chairs}

1 Vector Polarization

David L. Andrews, University of East Anglia (United Kingdom)

2 Optical Vortex Generation

David L. Andrews, University of East Anglia (United Kingdom)

3 Beam Properties

Daryl Preece, University of California, San Diego (United States)

4 Optical Angular Momentum

Enrique J. Galvez, Colgate University (United States)

5 Optical Structuring and Fabrication

Enrique J. Galvez, Colgate University (United States)

6 Chiral Interactions

Albert Ferrando, Universitat de València (Spain)

$7 \quad$ Structured Beams

Jörg B. Götte, University of Glasgow (United Kingdom)

8 Optical Information

Enrique J. Galvez, Colgate University (United States)

9 Optical Singularities

Daryl Preece, University of California, San Diego (United States)

10 Optical Forces

Daryl Preece, University of California, San Diego (United States)

11 Optical Manipulation

David L. Andrews, University of East Anglia (United Kingdom) 


\section{Introduction}

The areas described in the title of the conference proceedings are, before you pair them together, two of the most rapidly developing topics in modern optics. The links between various forms of structured light and novel forms of optical force represent an obvious and well established area of overlap, yet each field is in its own right experiencing much wider development. Across this whole field, there is closely matched progress in theory, technical methodology and application. As befits the subject area, this itself can be identified as a singular feature. Consider, alone, the angular momentum of light. Who could have guessed that a topic briefly that was addressed in a couple of innocuous-looking pages in Mandel and Wolf's classic from 1995 would soon proliferate into a subject that is now the focus of conferences across the globe? This year, for example, in addition to the trendsetting annual Complex Light and Optical Forces conference in the United States, major meetings are also scheduled in Canada, Germany, Italy, Japan and Ukraine.

Complex Light and Optical Forces laid down an initial marker for this field; the diversity of techniques continues to grow, whilst fundamental issues in the theory continue to present a significant challenge on several fronts. In this its eleventh consecutive run, this annual conference continues to be the "go-to" forum for reporting the very latest research achievements, with a committed and enthusiastic audience, and presenters who regularly include many of the world's top researchers. As conference chairs we are delighted and grateful to the authors, old and new, who contributed this year-and especially to those who have provided written or recorded accounts for these proceedings. Amongst the uniformly high standard, several describe features that are entirely new in this field. We thank every member of the program committee for their support. We also acknowledge the unfailingly supportive SPIE staff for assisting the conference organization in every way, and for ensuring speedy and professional processing of these proceedings.

David L. Andrews

Enrique J. Galvez Jesper Glückstad 
Proc. of SPIE Vol. 10120 1012001-12 Downloaded From: https://www.spiedigitallibrary.org/conference-proceedings-of-spie on 26 Apr 2023
Terms of Use: https://www.spiedigitallibrary.org/terms-of-use 